Tạp chi Khoa học và Công nghệ, Số 30, 2017

\title{
CRITICAL SUCCESS FACTORS (CSFs) FOR PUBLIC PRIVATE PARTNERSHIPS (PPP) IN MALAYSIAN
}

\author{
OH CHIN PHANG ${ }^{1}$, KIET NGUYEN TUAN ${ }^{2}$, HUNG LE VAN ${ }^{2}$, SOO-YONG KIM ${ }^{3}$, DAT LE HUU 4 \\ ${ }^{1}$ Interdisciplinary Program of Construction Engineering and Management, Pukyong National University \\ - Busan 608-737 - Korea, \\ ${ }^{2}$ Department of Civil Engineering, Industrial University of Ho Chi Minh City, \\ ${ }^{3}$ Department of Civil Engineering, Pukyong National University - Busan 608-737 - Korea, \\ ${ }^{4}$ Civil Engineering Faculty, University of Transport and Communications; \\ ocp_8182@yahoo.com,nguyentuankiet@iuh.edu.vn,hunglevan@iuh.edu.vn,kims@pknu.ac.kr, \\ lhdat@utc2.edu.vn
}

\begin{abstract}
Public Private Partnership (PPP) is an increasingly popular choice for policymakers in implementing important public projects. To ensure the ultimate objectives of PPP/PFI, identifying the critical success factors (CSFs) of PPP implementation is crucial. For countries that are new at adopting PPP it is even more important for them to identify the success factors in order to maximize the advantages of this method and to reduce the risks for all concerned parties. PPP was officially announced in Malaysia under the Ninth Malaysia Plan in 2006. Since then, many government projects were delivered via PPP. In this study, the factors that are considered critical to the success of PPP project implementation in Malaysia have become a subject for investigation. Factor analysis and survey expert were used in this case. The findings showed that the 17 CSFs could be grouped into six underlying factors. The main contribution of this study is supplement and improves knowledge in the management of PPP projects by exploring the relative importance of CSFs associated with PPP construction projects in the Malaysia. Several recommendations have been suggested in order to improve the overall performances of Malaysian PPP procurement.
\end{abstract}

Keywords. Public private partnership, Critical success factor, Malaysia.

\section{INTRODUCTION}

Over the last two decades, governments of a growing number of countries initiated public-private partnerships to let the private sector take over the responsibility for building an infrastructure and subsequently operating it to provide public goods or services. In industrialized countries as well as in emerging economies, public-private partnerships have been set up for large-scale projects in various sectors such as public transportation, health care, and education [1]. Most of the Commonwealth countries are using PPPs and PFIs to improve economic competitiveness and infrastructure services. Therefore, the Private Finance Initiatives (PFI) Programme was announced in the Ninth Malaysia Plan in March 2006, aimed at facilitating greater participation of the private sector to improve the delivery of infrastructure facilities and public service. It sets out many of the key principles on how some of the public sector infrastructure projects will be procured and implemented. PFI will be undertaken as part of the new modes of procurement under the Public-Private Partnerships (PPP) to further enhance private sector participation in economic development. The terms PPP and PFI have often been used inter-changeably throughout the world, for Malaysia, the PFI principles as announced in the Ninth Malaysia Plan form a subset of the umbrella PPP principles (PPP Unit, Prime Minister Department, 2009). PPP will be employed for infrastructure and service development projects that meet two conditions. First, the implementation of PPP must be able to make government projects more efficient where the risks and rewards are optimally shared between the two parties. Second, PPP is to be used where government support enhances the viability of the private sector projects in strategic or promoted areas (Ninth Malaysia Plan, 2006). From time to time, various public agencies in Malaysia have developed houses using the public-private partnership (PPP) approach. The few failed housing PPP projects captured by National Audit point to the necessity for proper implementation [18]. Though it may seem that PPP are the answer to governments' infrastructure funding problem, but 
there are many issues that need to be addressed before PPPs and PFIs can be used effectively as another form of public procurement, otherwise, these projects can turn out to be nightmares for policymakers and implementers. It is recognized that since the political, constitutional, legal economic and social circumstances of every country differ, there can never be a single blueprint of how a PPP programme works. Each government has to devise its own programme to suit local conditions. The Malaysian version of PPP is fundamentally at a young stage and there is no right or wrong in creating Malaysia's own version of PPP as long as holistic, structured and sustainable for procurement solution is in place because implementing PPP projects is not easy, but the benefits, if done properly, are many. Since PPP/PFI contracting still new in Malaysia, the contract clauses still contain gaps which subject to contractual deficiency issue. The deficiency refers to the missing elements of sustainable development in which is not properly tailored to PPP/PFI contracts. The challenge here depicts a consistent need in engaging the fundamental knowledge of sustainable development among professionals. Thus, the implementation of PPP/PFI contracts is in jeopardy [3]. The PPP contracts are urged to be constantly reviewed and revised by the Malaysian government to improve the present practice of PPP implementation to ensure the achievement of its ultimate objectives [23]. For countries that are new at adopting PPP it is even more important for them to identify the success factors in order to maximize the advantages of this method and to reduce the risks for all concerned parties [5]. Therefore, the factors that are considered critical to the success of PPP project implementation in Malaysia have become a subject for investigation.

This study is attempted to fill in the gap by exploring and re-examining the critical success factors (CSFs) necessary for adopting public private partnerships (PPPs) in Malaysian construction industry, in general, without referring to any specific PPP sector or project. Therefore, this research aims to supplement and improve the knowledge in managing PPP projects by exploring the relative importance of CSFs associated with PPP construction projects in the Malaysia. Second, this research intends to aid PPP users to improve their understanding of critical success factors of current Malaysian PPP in the early stage of projects through different perspectives of respective public and private sector participants because each party plays a different role in PPP procurement. In addition, this research also aims to provide a guideline of possible improvements and strategy that could be executed in strengthening PPP implementations by government in order to form an ideal Malaysian version of PPP that able to deliver better quality of service in future. Thus, to facilitate this particular aims, objectives have been formulated namely:

- To identify the relative importance of the CSFs that contributes to the success of the implementation of PPP as perceived by the overall respondents in Malaysian Construction Industry

- To identify and examine the differences in perception concerning the relative importance of the CSFs between the public and private sectors in Malaysian Construction Industry

\section{LITERATURE REVIEW}

\subsection{Public Private Partnership (PPP)}

Akintoye et al. [6] define PPPs as a long-term contractual arrangement between a public sector agency and a private sector concern, whereby resources and risk are shared for the purpose of developing a public facility. The principal aim of a PPP for the public sector is to achieve value for money in the services provided while ensuring that the private sector entities meet their contractual obligations properly and efficiently [7]. PPPs are a means of public sector procurement using private sector finance and best practice. PPPs can involve design, construction, financing, operation and maintenance of public infrastructure and facilities, or the operation of services, to meet public needs. They are often privately financed and operated on the basis of revenues received for the delivery of the facility and/or services.

One key to this is the ability of the private sector to provide more favourable long term financing options than may be available to a government entity and to secure the financing in a much quicker time frame (The National Council for Public - Private Partnerships (NCPPP), 2003). Such contracts are longterm in nature and typically 25-30 years. According to Mustafa (1999), PPPs address the common faults that are associated with public sector procurement such as high construction costs, construction overruns, operational inefficiencies, poor design, and community dissatisfaction. The PPP is founded on transfer of risk from the public to the private sector under circumstances where the private sector is best placed to 
manage risk. One of the key features of the PPP which is appealing to the government is the shift of project risks from the public sector to the consortium involved with the project even though this requires a profit incentive to the project consortium [7]. PPPs are being established as a cost effective method of overcoming costs associated with the provision and maintenance of infrastructure. Duffield [8] identifies recent Australian examples of PPPs that include the New Prisons Project in Victoria, New South Wales Schools Project and Sydney's Cross City Tunnel.

PPPs have multiple objectives including promoting infrastructure development, developing local economy, reducing costs, increasing construction and operation efficiencies, and improving service quality by incorporating the private sector's knowledge, expertise and capital (Yuan et al., 2009). When PPP projects were first launched in the UK, the government appeared to view them primarily as a way of getting infrastructure costs of the public balance sheet, keeping investment levels up, cutting public spending and avoiding the constraints of public sector borrowing limits (Li et al., 2005). However, Li et al. (2005) argue that the impact of government borrowing is much less significant than at first thought and that PPP is now seen as essentially a new approach to risk allocation in public infrastructure projects. Li (2003) demonstrates that the most significant factors associated with PPP procurement are: a lot of management time spent in the contract transaction, lengthy delays in negotiation and high participation cost. Problems reported with PPP procurement include: high cost of tendering, complex negotiation, cost restraints on innovation, and differing or conflicting objectives among the project stakeholders [12].

Public Private Partnership (PPP) procurement processes are complex, given both the longer time frames and wider scope of services contracted. Besides, the numerous parties involved in a PPP project make the stakeholder relations much more complex than in other procurement systems. The increasing frequency and significance of PPP is accompanied by problems of instability and poor performance [13].

One major problem that has been encountered is the slow progress in the execution of BOT [14]. There are other serious problems like legal, political, environmental, etc. that have even led to failures of BOT projects worldwide. For example, the strong public opposition to some privatized projects in the Lao PDR [15] and in some states in the USA [16], the failures of two BOT projects in Thailand due to political instability and other reasons [17] and the failure of Malaysia's privatized national sewerage project [18].

Clearly, such problems are not costless. PPP typically involves commitment of substantial resources from both sides. Therefore, failure can result in a loss of competitive position far beyond merely the opportunity cost of the resources deployed in the PPP itself; while synergistic gains and expected positive spillover effects for the parent organization may not be realized [19].

\subsection{Critical success factors (CSFs) in PPP}

Rockart [20] defines CSF as those relatively small numbers of truly important matters where a particular industry should focus her attention in order to achieve success. They represent "factors" which are "critical" to the "success" of the industry concerned in Rockart's studies. Rockart [20] elaborated that the key to success is to focus the most limited resources (usually time) on the things which really make the difference between success and failure. Sanvido et al. [30], Tiong [21] and Cooke-Davies [22] also defined CSFs as those factors which are necessary for the project participants to achieve their goals in a project.

In terms of CSFs of PPP projects, studies have emerged since the 1990s [23]. Tiong [21] identified CSFs in PPP projects based on BOT model as project technical feasibility; strong private consortium; stable macro-economic environment; and favourable legal framework. Qiao et al. (2001) identified CSFs as stable macro-economic environment; technical innovation and technology transfer; available financial market; political stability and social support; good governance; and projects technical feasibility.

The UK has a long history in adopting the PPP model. Consequently, there has been a large number of studies produced looking at factors leading to successful PPP projects. For example, Pinder [25] conducted a questionnaire survey with 701 respondents in the UK involved with the PPP process. The findings highlighted four main critical success factors for conducting PPP projects including: well-drafted output specification; a robust business case; committed senior management; and full consultation with endusers. Li et al.'s [31] study was also conducted in the UK at a similar time as Pinder et al.'s. They found both similar and dissimilar findings. The factors contributing to successful projects included: effective procurement; project implement; government guarantee; favorable economic conditions; and available financial market. 
Kwak et al. [26] were also interested in looking at the factors contributing to successful PPP projects. Consequently, they analyzed five relevant research studies of different jurisdictions. The findings indicated that there were four main aspects which would lead to successful PPP projects in general.

In jurisdictions that are new to delivering PPP projects, researchers found that the successful implementation requires a stable political and social environment. This environment heavily relies on the stability and capability of the host government [27]. Unstable political and social environments have resulted in some failed rail projects. For example, in Bangkok, the frequent change in government premiers has led to the cancellation of many new public infrastructure projects originally procured under the PPP approach [29].

In respect of specific case studies, Jefferies et al. [28] examined the CSFs of a stadium in Australia, which was built using the Build Operate Own Transfer (BOOT) mode of PPP. The authors identified and examined 15 success factors relevant to the project and the most significant CSFs include: 'compatibility/complimentary skills among the key parties', 'technical innovation in overcoming project complexity' and 'efficient approval process'. Likewise, Jefferies [28] investigated the CSFs of the Super Dome PPP project, which was also constructed using the BOOT scheme.

Jamali [32] investigated the CSFs for PPP implementation in the telecommunication industry in Lebanon. Using a case study approach, the findings indicate that 'trust', 'openness' and 'fairness' are basic foundational underpinnings of successful PPPs. Zhao et al. [33] investigated the factors contributing to the success of two PPP power projects - thermal power and wind power - that were developed using the Build Own Transfer (BOT) mode.

In particular, the research of $\mathrm{Li}$ et al. [31] had conducted an extensive review into the success factors and summarized them into eighteen CSFs. Factor analysis was subsequently carried out to classify these factors into five main groups. Abdul Aziz [2] adopted a questionnaire survey and interviews to examine the CSFs of ten PPP housing projects in Malaysia. The results reveal that all 18 factors except 'political influence' contribute significantly to the success of a PPP housing project.

\section{RESEARCH METHOD}

\subsection{Research methodology}

Prior to considering the objective of re-exploring the principal factors essential to the success of the PPP construction project will help in gaining a better insight towards the industry, the current practice of the PPP in Malaysian construction industry should be investigated first. Then follow by the investigation of critical success factor of PPP in Malaysia construction industry. In order to gain the research purposes as mentioned in the previous chapter, a conceptual framework is drawn in step-by-step as shown in Figure 1.

\subsection{Survey population}

A randomly selected group of targeted respondents consists of personnel who have a role in the Malaysia PPP construction process and resource management, and extensive site experiences were targeted as respondents for the sample survey. There is a wide spectrum of personnel with different position and job title. The public and private sectors in PPP projects will have some common goals but they will also have several project and long-term aims that are very different. Therefore, the whole sample of respondents can be regrouped into two main categories as follows:

- Public sector orientated group (Government): The officers with practical experience of PPP/PFI in relevant government departments will be targeted.

- Private sector orientated group: The private sector group will cover industry practitioners including developers, consultants, contractors and investment bankers who are experienced in PPP schemes.

\subsection{Questionnaire survey}

Due to the unavailability of documented data of completed projects for research in Malaysia, a questionnaire survey has been decided to be employed. The role of questionnaire is to provide a standardized interview across all subjects. All respondents are asked the questions that are appropriate to them, and so that, when those questions are asked, they are always asked in the same way (Brace, 2004). 
The difficulty of this study is the far distance between the researcher and the targeted respondents. Therefore, the questionnaire has been considered as the most sufficient way of remote communication between them. The questionnaire survey can be basically divided into three steps: (1) Questionnaire design, (2) Questionnaire distribution, and (3) Data collection and preliminary analysis.

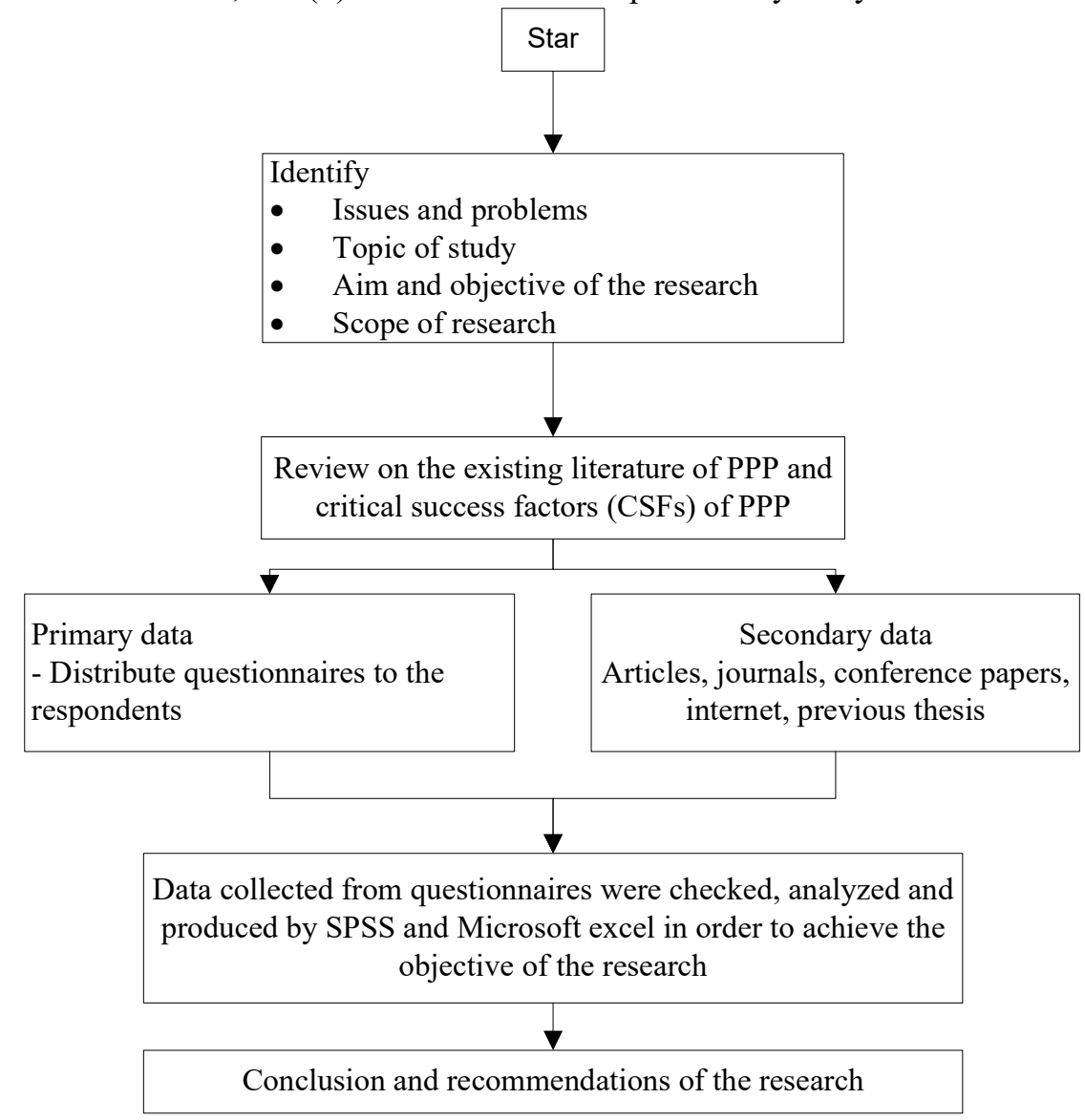

Figure 1. The Conceptual Research Framework.

\subsubsection{Questionnaire design}

In this step, pilot test with experts group will be conducted to test the suitability of the questionnaire. Before conducting the pilot test, potential items were extracted from literature review and practitioners in professional forum. These works help to form a preliminary questionnaire. It is decided to test this draft version of the questionnaire with experts. A group of three experts were invited to take part in the pilot test. All these experts are practitioners in the PPP. They have much experience in PPP construction engineering and management with at least ten years involved in construction field. The experts are asked to review the sufficiency and appropriateness of the problems and the structure of the questionnaire. After that, all items which are considered as potential problems for research objectives are finalized in the official questionnaire.

\subsubsection{Questionnaire distribution}

The main purpose of this research is to explore and re-examining the critical success factors (CSFs) necessary for adopting public private partnerships (PPPs) in Malaysian construction industry, in general, without referring to any specific PPP sector or project. A quantitative research approach is adopted for this research requiring the development and dissemination of a questionnaire survey. Due to the population of this research are virtually very difficult to be quantified as the main targeted respondents would include all personnel who have direct involvement in PPP construction field, the non-probability sampling methods will be adopted in this research instead of probability sampling. 
In Malaysia, there is no organization recording or managing the PPP construction practitioners' profiles. Therefore, the researcher employs a self-administered questionnaire distribution. The involved practitioners in the survey are identified through construction companies' websites and charters, professional forum, project case analyses, and researcher's personal relationship. It is noted that the brief information about the definition of critical success factor of PPP is described at the beginning section of the questionnaire. Two main methods for delivering the questionnaire are adopted in this study including electronic mailing and internet survey link. The area of sampling is in whole Malaysia. The first duration for collecting mass data is one month. After one month, a remind contact is conducted to people who do not reply the questionnaire. All responses after this due day will be discarded.

\subsubsection{Preliminary analysis}

The main purpose of this step is to collect and filter the feedbacks from the respondents. All the raw collected data will be put in a prepared sheet of Microsoft Excel for preliminary treatment. Questionnaires which are not fully answered by respondents will be discarded in this step. The data will be then classified into qualitative data and quantitative data. Moreover, they are also classified into data that need to be solved by inferential statistical tools or descriptive statistical tools.

The appropriate responses are then entered into the statistical software, namely Statistical Package for the Social Science (SPSS, version 18.0). This activity makes out the data set for this study. The detailed analysis results and discussion are presented in the following chapter.

\subsection{Expert survey}

The main purpose of expert's survey is to request for their help with the accuracy of the research problems. In detail, before conducting to collect mass data, referring the opinions of experts to certify the feasibility of the research problems is needed. Furthermore, the confirmation of experts to the results of analysis is also required in this study. These actions make the study more reliable and practical. They can also fill their comments at the end of the check sheet that they think these comments are helpful to the research findings.

\subsection{General characteristics of respondents}

A questionnaire (in Malaysia) consisting of eighteen critical success factors was designed. A total of 250 copies of the questionnaire have been distributed to the personnel in Malaysia. Responses were received from 60 professionals. After filtering these, only 55 responses were found to be usable. Thus, the effective rate of response in this study is $18 \%$. This rate is higher than that of an earlier Institute for Public Policy Research (IPPR, 2000) survey dealing with PPP which achieved a response rate of $9.6 \%$ and similar to return rates achieved in comparable contemporary survey research reported in construction and project management journals. The results illustrate that the total number of respondents was 55 , with $25(45.5 \%)$ engaged in the public sector and $30(54.5 \%)$ engaged in the private sector. More than $27.3 \%$ of respondents in the survey are engineers. Other respondents consist of project managers/ planners $(20 \%)$, lecturer/ professor $(14.5 \%)$, architect $(9.1 \%)$, managers $(5.5 \%)$, and others $(9.1 \%)$. The quite large proportion of top and functional personnel confirms the reliability of collected data for identifying critical success factor in Malaysian PPP projects. $87 \%$ of the respondents possessed more than five years of working experience with 36 percent of respondents having over sixteen years of industrial experience. In addition, approximately 94 percent of the respondents have participated in PPP projects before, with 54 percent of the total respondents having previously been involved with at least five PPP projects.

The proportion of respondents in terms of involvement in number of PPP projects are: none (5.5\%), one project (12.7\%), less than five projects $(27.3 \%)$, between six to ten projects $(30.9 \%)$, and more than or equal to eleven projects $(23.6 \%)$. Overall, the background of the respondents reflects their credibility in providing reliable information for the purpose of the present study. 


\section{FACTOR ANALYSIS}

\subsection{Ranking of the perceived importance of CSF in PPP}

The relative importance of the 18 CSFs identified from the literature review was explored by means of Likert rating scale questions in the survey instrument. This type of scale has been found to be acceptable in other construction management research. The analysis of the survey response data produced mean importance values for the eighteen CSFs ranging from 4.53 to 3.36. Table 4.1 shows that thirteen factors scored mean values greater than 4.0, five factors displayed mean importance values between 3.0 and 4.0. Among the 18 CSFs in the survey, the top five critical success factors of overall respondents' perceptions were analyzed and discussed further.

Based on the overall respondents' result, the top five most critical success factors, in descending order of importance are: 1) Commitment and responsibility of public and private sectors; 2) Transparency in the procurement process; 3) Multi-benefit objectives; 4) Good governance; and 5) Project technical feasibility. The two factors that were ranked as least important for success PPP projects are social support and political support.

Table 4.1. Survey respondents' perceptions of the relative importance of CSFs in PPP projects.

\begin{tabular}{|c|c|c|c|c|c|c|c|}
\hline \multirow[t]{2}{*}{ No. } & \multirow[t]{2}{*}{ Critical Success Factor } & \multicolumn{2}{|c|}{ Public } & \multicolumn{2}{|c|}{ Private } & \multicolumn{2}{|c|}{ Overall } \\
\hline & & Mean & Rank & Mean & Rank & Mean & Rank \\
\hline 1 & $\begin{array}{l}\text { Commitment and responsibility of both public } \\
\text { and private sectors }\end{array}$ & 4.60 & 1 & 4.47 & 2 & 4.53 & 1 \\
\hline 2 & $\begin{array}{l}\text { Transparency in the procurement process } \\
\text { (process is made open and public) }\end{array}$ & 4.48 & 2 & 4.50 & 1 & 4.49 & 2 \\
\hline 3 & Multi-benefit objectives & 4.32 & 5 & 4.43 & 3 & 4.38 & 3 \\
\hline 4 & Good governance & 4.40 & 4 & 4.30 & 7 & 4.35 & 4 \\
\hline 5 & Project technical feasibility & 4.24 & 7 & 4.37 & 5 & 4.31 & 5 \\
\hline 6 & Well-organized public agency & 4.28 & 6 & 4.30 & 9 & 4.29 & 6 \\
\hline 7 & Thorough and realistic cost/benefit assessment & 4.24 & 8 & 4.33 & 6 & 4.29 & 7 \\
\hline 8 & Available financial market & 4.12 & 11 & 4.40 & 4 & 4.27 & 8 \\
\hline 9 & $\begin{array}{l}\text { Competitive procurement process (enough } \\
\text { potential bidders in the process) }\end{array}$ & 4.48 & 3 & 4.10 & 14 & 4.27 & 9 \\
\hline 10 & Sound economic policy & 4.16 & 10 & 4.30 & 8 & 4.24 & 10 \\
\hline 11 & Appropriate risk allocation and risk sharing & 4.16 & 9 & 4.27 & 10 & 4.22 & 11 \\
\hline 12 & Strong private consortium & 4.04 & 14 & 4.27 & 11 & 4.16 & 12 \\
\hline 13 & $\begin{array}{l}\text { Stable macro-economic environment including } \\
\text { low inflation, stable exchange and interest rates }\end{array}$ & 4.04 & 15 & 4.20 & 12 & 4.13 & 13 \\
\hline 14 & $\begin{array}{l}\text { Shared authority between public and private } \\
\text { sectors }\end{array}$ & 4.08 & 12 & 3.93 & 15 & 4.00 & 14 \\
\hline 15 & Favorable legal framework & 3.80 & 16 & 4.13 & 13 & 3.98 & 15 \\
\hline 16 & $\begin{array}{l}\text { Government involvement by providing } \\
\text { guarantees }\end{array}$ & 4.04 & 13 & 3.83 & 17 & 3.93 & 16 \\
\hline 17 & Social support & 3.72 & 17 & 3.83 & 16 & 3.78 & 17 \\
\hline 18 & Political support & 3.36 & 18 & 3.37 & 18 & 3.36 & 18 \\
\hline
\end{tabular}


The 'commitment and responsibility of both public and private sectors' was ranked first (Table 4.1: mean value of 4.53) as the most important critical success factor to ensure the success of PPP projects. Commitment is one of the fundamental principles in partnership because it is important to manage the relationship between partners, to contribute to the success of a PPP project. All parties should put in their best resources (financial, human, etc.) to the partnership project. Commitment should be established throughout all management levels, not only within the special purpose vehicle established for the project, but also in the parent companies or steering boards [31]. Therefore, commitment from both parties is essential to ensure the attainment of the ultimate goals of the PPP projects. In addition, how such commitment can be assessed (or benchmarked) raises interesting issues for further research.

The 'transparency in the procurement process' is the second important CSF for implementing PPP project in Malaysia, as perceived by overall respondents with mean value of 4.49 as shown in Table 4.1. A transparent and efficient procurement process is essential in lowering the transaction costs and shortening the time in negotiation and completing the deal. Clear projects' briefing and client requirements should help to achieve these in the bidding process. In most cases, competitive bidding solely on price may not help to secure a strong private consortium and obtain value for money for the public. The government should take a long-term view in seeking the right partner. Hence, transparency in tender processes (NAO, 2001a), which further suggests that three features are important for transparency: good communication between the public and private contractor and their advisers; the private sector openly consulting with the public sector and its adviser, while keeping responsibility for all decisions; and the private sector establish a clear basis for making decisions. For public accountability, public agencies need to maintain fair, open, and transparent processes for the procurement of public projects. Consequently, governments may take several steps to maintain the accountability requirements by maintaining a disclosure practice that aims at disclosing as much information as possible without jeopardizing the competitive process, maintaining the government negotiating position and its ability to generate the best value for taxpayers' money, and protecting the private sector's sensitive information. In Malaysia, normally government will take control on the selection of private company in the tendering process without publishing the important information to public and everything seems to be done in a closed process without considering any opinions or recommendations from the public. Transparency of process therefore requires effective communication that is open as much as possible to public scrutiny. Thus, respondents believed that the government needs to make concerted efforts to make the public aware of the whole procurement process in the PPP projects in order to make the procurement process more transparent towards the general public. Indeed, an objective, competitive and fair transparent procurement process is conducive to the successful implementation of a PPP project; otherwise, legal battle would be invoked easily.

The third most important CSF for implementing PPP projects in Malaysia is the 'Multi-benefit objectives', as perceived by overall respondents in the survey with the mean value of 4.38 in Table 4.1. To develop a successful PPP/PFI project, all parties should agree on multi-benefit objectives. For a long-term partnership, PPP/PFI partners must understand and respect each other's goals. Typically, the objectives of the public sector party relate to reduction in financial restraints, avoiding public finance restriction, effective provision of public goods and services (detailed by specific project), the transfer of risk and the achievement of value for money. Private sector objectives are typically profit generation and market penetration, diversification and technology and skills acquisition, while the objectives of the stakeholder user communities are to receive better services or to occupy a better environment. If there is no multi-benefit objectives exist in a PPP projects, government and private company need to re-examine the value of money for the good of final user. Otherwise, the ultimate objective of implementation of PPP cannot be achieved via transferring responsibility to finance and manage capital investment and services from the public sector to the private sector in return for lease charges that are commensurate with the quality of services and an amount sufficient to ensure commercial returns on investment [34].

'good governance' is the fourth most necessary success factor for PPP projects in Malaysia. It is crucial to have good governance, as claimed by the United Nations Economic Commission for Europe [35], because inefficiency in governance has led to the failure in the implementation of PPP in many countries. Therefore, good governance (mean value 4.35) is important for the success of PPP/PFI in terms of developing sound economic policy and in administrating projects. Badshah [36] emphasizes that good 
governance is essential to attract private sector participation in public services delivery. Mustafa [37] put the policymakers at the apex of PPP/PFI structures, and recognized their dominant influence in determining the development of PPP/PFI. The National Health Service (NHS, 1999) regards the Chief Executive as its highest level of PFI project governance, with ultimate responsibility for delivering the project. In UK PFI projects, most authorities and contractors consider that governance arrangements are working well [38].

The fifth ranked factor is 'project technical feasibility' with mean value of 4.31. Project technical feasibility is important to the private sector for winning a PPP/PFI contract in the tendering process [21]. A SPECIAL PURPOSE VEHICLE must demonstrate that the technical aspects of a proposal will satisfy all relevant regulatory requirements. Novel technology adds to the riskiness of projects. In an Australian PPP BOOT project for a new city tollway, commissioning difficulties with an advanced electronic tolling system delayed the opening of the road for several months. Government pressure (resulting from newspaper criticism) then forced the opening as a toll-free facility for a part of this period, thus significantly affecting project revenue streams until the defective tolling system could be rectified. On the same project, the need to find an effective solution to water leaks in a newly built tunnel delayed the opening of another section of the toll way and led to adverse reactions by potential users.

In Malaysia, there is a Smart tunnel project which applied PPP as the procurement of the project. The purpose of smart tunnel is built to discharge excess flood water but smart tunnel fail to function well as planned in preliminary design. This is due to the mistake in the project technical feasibility study at the design stage of PPP project. Therefore, technical assessment is important in the project technical feasibility of a PPP project because technical assessment involves the evaluation of designs and the planned facilities in a life cycle scenario including environmental impacts and safety and health considerations. Value engineering techniques can be deployed to improve benefit/cost profiles of potential technical solutions, particularly in the assessment of unsolicited or alternative technical proposals. In addition to strengths in formulating advantageous technical packages, the concessionaire should also have strong managerial capabilities, including leading role by a key enterprise or entrepreneur, workable project organization structure, good relationship with host government authorities, partnering skills, rich experience in international PPP project management, multidisciplinary participants, and a strong project team.

According to the Asian Development Bank [38], the government, as a political decision maker, has to set out the case for PPP in a convincing and transparent manner and any political changes can hinder the PPP implementation. In other words, politics has a close relationship with the development and implementation of public policy [31]. Of the $18 \mathrm{CSFs}$ 'political support', with a mean value of 3.36 in Table 4.1, was ranked last by the respondents. The result does not mean that political support is not an important factor for successful PPP implementation in Malaysia, as this could be due to the fact that in Malaysia the current political situation is stable and clear government policy for implementation of PPP projects. In addition, the government is in support of PPP by established the Public Private Partnership Unit (3PU) to manage the PPP projects and issued PPP/PFI Guidelines aiming to address some of the key attributes of the PPP/PFI model. Therefore, this success factor is being perceived as relatively less critical compare to the other critical success factor in the CSFs list.

Table 4.2. Results of KMO and Barlett's Test for the CSFs of PPP.

\begin{tabular}{|l|l|c|}
\hline \multicolumn{2}{|l|}{ KMO measure of sampling adequacy } & 0.694 \\
\hline Bartlett's test of sphericity & Approximate chi-square & 567.732 \\
\hline & Degree of Freedom & 153 \\
\hline & Significance & 0.000 \\
\hline
\end{tabular}

The factor grouping based on varimax rotation is shown in Table 4.4. Each variable belongs to only one of the factors, with the loading on each factor exceeding 0.50. It is noticed that the CSF appropriate risk allocation and risk sharing does not belong to any of the factor groupings, and therefore cannot be grouped in this way. 
Table 4.3. Total rotated factor variance explained for critical success factors for PPP projects.

\begin{tabular}{|c|c|c|c|c|c|c|}
\hline \multirow[t]{2}{*}{ Component } & \multicolumn{4}{|c|}{ Initial Eigenvalues } & \multicolumn{2}{|c|}{ Rotation Sums of Squared Loading } \\
\hline & Total & $\begin{array}{c}\% \text { of } \\
\text { variance }\end{array}$ & Cumulative $\%$ & Total & $\begin{array}{c}\% \text { of } \\
\text { variance }\end{array}$ & Cumulative $\%$ \\
\hline 1 & 6.261 & 34.782 & 34.782 & 4.083 & 22.683 & 22.683 \\
\hline 2 & 2.240 & 12.447 & 47.229 & 3.541 & 19.674 & 42.357 \\
\hline 3 & 1.658 & 9.210 & 56.439 & 1.697 & 9.426 & 51.783 \\
\hline 4 & 1.434 & 7.968 & 64.407 & 1.606 & 8.923 & 60.706 \\
\hline 5 & 1.267 & 7.039 & 71.445 & 1.602 & 8.902 & 69.608 \\
\hline 6 & 1.033 & 5.740 & 77.186 & 1.364 & 7.578 & 77.186 \\
\hline 7 & 0.707 & 3.897 & 81.082 & & & \\
\hline 8 & 0.634 & 3.524 & 84.606 & & & \\
\hline 9 & 0.549 & 3.049 & 87.655 & & & \\
\hline 10 & 0.507 & 2.819 & 90.474 & & & \\
\hline 11 & 0.413 & 2.296 & 92.770 & & & \\
\hline 12 & 0.322 & 1.790 & 94.560 & & & \\
\hline 13 & 0.292 & 1.622 & 96.182 & & & \\
\hline 14 & 0.220 & 1.224 & 97.406 & & & \\
\hline 15 & 0.168 & 0.935 & 98.341 & & & \\
\hline 16 & 0.147 & 0.815 & 99.156 & & & \\
\hline 17 & 0.100 & 0.557 & 99.713 & & & \\
\hline 18 & 0.052 & 0.287 & 100.000 & & & \\
\hline
\end{tabular}

Table 4.4. Rotated factor matrix (loading) of critical success factors for PPP.

\begin{tabular}{|l|c|l|l|l|l|l|}
\hline \multirow{2}{*}{ Factor Component } & \multicolumn{5}{c|}{ Component } \\
\cline { 2 - 7 } & Group 1 & Group 2 & Group 3 & Group 4 & Group 5 & Group 6 \\
\hline Available financial market & 0.843 & & & & & \\
\hline Project technical feasibility & 0.798 & & & & & \\
\hline Favourable legal framework & 0.778 & & & & & \\
\hline Strong private consortium & 0.747 & & & & & \\
\hline Well-organized public agency & 0.729 & & & & & \\
\hline Stable macro-economic environment & 0.537 & & & & & \\
\hline Good governance & & 0.857 & & & & \\
\hline $\begin{array}{l}\text { Thorough and realistic cost/benefit } \\
\text { assessment }\end{array}$ & & 0.853 & & & & \\
\hline Social support & & 0.740 & & & & \\
\hline $\begin{array}{l}\text { Shared authority between public and } \\
\text { private sectors }\end{array}$ & & 0.644 & & & & \\
\hline
\end{tabular}




\begin{tabular}{|l|l|l|l|l|l|l|}
\hline $\begin{array}{l}\text { Government involvement by providing } \\
\text { guarantees }\end{array}$ & & & 0.828 & & & \\
\hline $\begin{array}{l}\text { Commitment and responsibility of public } \\
\text { and private sectors }\end{array}$ & & & 0.670 & & & \\
\hline Competitive procurement process & & & & 0.730 & & \\
\hline Sound economic policy & & & & 0.668 & & \\
\hline Political support & & & & & 0.880 & \\
\hline Transparency in the procurement process & & & & & 0.530 & \\
\hline Multi-benefit objectives & & & & & & 0.874 \\
\hline $\begin{array}{l}\text { Appropriate risk allocation and risk } \\
\text { sharing }\end{array}$ & & & & & & \\
\hline
\end{tabular}

In order to facilitate the explanation of the results of FA, it is necessary to assign an identifiable, collective label to the groups of individual factors of high correlation coefficients, as each of the underlying grouped factors is an aggregation of individual factors (Sato, 2005). It is however stressed that the suggested label is subjective and other researchers may use a different label. The factor analysis shows that the residual 17 CSFs can be grouped into six principal factors and be interpreted as follows: factor grouping 1 represents project implementability, factor grouping 2 represents shared responsibility between public and private sectors, factor grouping 3 represents government guarantee, factor grouping 4 represents efficient procurement process, Factor grouping 5 represents political support, factor grouping 6 represents multibenefit objectives. The meanings of the six underlying grouped CSFs of PPP in this study are interpreted as follows.

\subsubsection{Factor Grouping 1- Proj ect Implementability}

This principal factor is responsible for $22.68 \%$ (Table 4.3 ) of the total variances of critical success factors. These CFSs are all related to ensuring a good foundation for the project's implementability. The CSFs under this underlying group cover financial market issues, technical issues, legal issues and economic issues in order to adopting PPP. The first CSF in this group is available financial market (Table 4.4: significance 0.843 ). Many researchers have found out that project financing is a key factor for private sector investment in public infrastructure projects. The availability of an efficient and mature financial market with the benefits of low financing costs and a diversified range of financial products would be an incentive for private sector taking up PPP projects. The CSF with the next highest factor loading is project technical feasibility, which has a significance of 0.798 in Table 4.4. Traditionally, technical issues are among the most important considerations in a project feasibility study. When considering PPP procurement options, it is important to review the associated technical problems. In particular, the private contractor needs to ensure that any engineering uncertainties are resolved.

Third CSF is a favourable legal framework (Table 4.4: significance 0.778). A favourable legal framework allows a PPP/PFI project to be developed without undue legal restriction on the private sector involvement. An appropriate risk framework should guarantees the legal status for project implementation. An adequate dispute resolution system should help to ensure stability in the PPP arrangements. Appropriate governing rules, regulations, and reference manuals related to PPP have been well-established in some developed countries (e.g., U.K., Australia, Canada, South Africa, etc.) to facilitate the effective application of PPP procurement approach.

A strong private consortium is fourth loading component in the group (Table 4.4: significance 0.743). This relates to project implementability in the sense that where a project has the right actors (stakeholders), with common goals, the project is most likely to be implemented successfully. The government in contracting out the PPP projects should ensure that the parties in the private sector consortium are sufficiently competent and financially capable of taking up the projects. This suggests that private companies should explore other participants' strengths and weaknesses and, where appropriate, join 
together to form a consortia capable of synergizing and exploiting their individual strengths. Good relationship among partners is also critical because they all bear relevant risks and benefits from the cooperation.

The fifth CSF in this group is well-organized public agency (Table 4.4: significance 0.729). A wellorganized public agency to negotiate on behalf of the public body is essential for a PPP/PFI project. In project procurement generally, the team, including project owner, project sponsor and project manager, should possess essential management ability and technical ability. It might be appropriate to seek external skills and experience from competent advisers to complement public sector skills. However, the cost of such advice has to be added into the financial assessment of the project at the outset.

The CSF with the lowest factor loading in this group is stable macro-economic environment with significance of 0.537 (Table 4.4). Li et al. [31] mentioned that, for successful PPP project implementation, governments must ensure that economic conditions are favourable. A stable macro-economic environment, where the market exhibits reasonable certainty and market risk is correspondingly low, does a great deal (e.g. low inflation, stable exchange and interest rates) to reduce risks for private investors. The government can help to create and maintain a stable economic environment by manipulating economic policy levers to ensure stable prices and by maintaining a balanced budget for PPP projects.

\subsubsection{Factor Grouping 2- Shared Responsibility between Public and Private Sectors}

This principal factor is responsible for $19.67 \%$ (Table 4.3) of the total variances of critical success factors. This underlying group consists of four CSFs including: 'Good governance', 'Thorough and realistic cost/benefit assessment', 'Social support', 'Shared authority between public and private sectors'

The CSFs under this underlying group mainly focus on the main characteristic of government in PPP and sharing of responsibilities and authority between the main parties in a PPP arrangement. In addition, this group also covers those CSFs related to the social support and assessment of benefits.

The first CSF in this group is good governance (Table 4.4: significance 0.857). Good governance is essential to attract private sector participation in public services delivery. A committed and knowledgeable public client will be able to coordinate with the private parties much more effectively. The public client will also act as a monitoring authority to ensure that the private consortium acts according to the agreement. The second CSF in this group is thorough and realistic assessment of the cost and benefits (Table 4.4: significance 0.853). For this CSF, $\mathrm{Li}$ et al. [31] also explained that before a project is subjected to the procurement process, the public client should ensure that all the potential options that are beneficial to the government and end-users are considered as part of the complete project feasibility study. The public and private sectors have different views on project financial analysis. Of great importance is how uncertainty is to be treated in such assessment, as in the project development stage both costs and benefits are derived from forecasts projected over anything from three to 30 years. Although much of this assessment is treated as commercial-inconfidence, some forecasts may need to withstand open public scrutiny.

To conduct PPP/PFI procurement, social support is an important component (Table 4.4: significance 0.740) because social support is based on the public acceptance of the concept of private provision. Public opinion against PPP/PFI could slow, or even prevent, the project development. Social support therefore helps a PPP/PFI development and procurement process to go smoothly, particularly at the earlier stages, such as during land acquisition.

\subsubsection{Factor Grouping 3- Government Guarantee}

Government guarantee is important in the early stage of PPP/PFI evolution. It accounts for $9.43 \%$ (Table 4.3) of the total variances in the factor analysis of CSFs. There are two components in this principal factor: government involvement by providing a guarantee; and commitment and responsibility of public and private sectors. Higher loading is associated with government involvement by providing a guarantee (Table 4.4: significance 0.828). In the current Malaysian PPP situation, the private sector does not yet have full confidence in PPP procurement and is subsequently demanding revenue guarantees or firmly committed policies from government to ensure that investments are protected. Therefore, governments can provide PPP/PFI project guarantees in a variety of ways. Subsidy guarantees for housing, agriculture, students, exports and public corporations tend to dominate the picture in countries, especially where prices 
or user charges have been set too low and the government is not willing to raise them, nor allow them to be raised by the private sector provider.

The ideal guarantees from government tend to lower the risk taken by the concessionaire, support the cash flows of the concessionaire, and raise the level of confidence of investors and lenders. However, in developed countries, the government would not provide such a direct and attractive package to private investors. The guarantee from government must not only cover the revenue issues and government should guarantee provide the flexible policy and strong support to private company in solving the related problem in PPP projects. Under PPP contracts the government should be concerned that the assets are procured and services are delivered on-time with good quality and meet the pre-agreed service benchmarks or requirements throughout the life of the contract.

However, the government should be less concerned with "how" these are achieved and should not impose undue restrictions and constraints on private sector participants. The government should focus on industry and service regulation; should be flexible in adopting innovations and new technology; and should provide strong support and make incentive payments to the private sector where appropriate. On the other hand, the government should retain controls in case of default and be prepared to step in and re-provide the service if necessary.

\subsubsection{Factor Grouping 4- Efficient Procurement Process}

This factor group accounts for $8.92 \%$ (Table 4.3) of the total variability between critical success factors. There are two CSFs under this underlying group. These CSFs are related to the procurement process of PPP projects and they included competitive procurement process (enough potential bidders in the process) and sound economic policy. Higher loading is associated with competitive procurement process (Table 4.4: significance 0.730). Hall (1998) insists that value for money (VFM) gains depend on the existence of a competitive bidding process. The National Audit Office [38] notes that government departments should establish three key conditions for successful competitive tender: a good tender list of firms invited to bid; a clear specification in requirements; and competitive tension maintained throughout the procurement process. For instance, some Malaysian PPP projects involved direct negotiation with the relevant parties, which eliminating the competition in tendering. This negotiation method in tendering might increase the risk of financial and construction for all respective parties in the PPP projects. Thus, there is a need of third party independent checking group for close monitoring on the negotiation process in tendering to make sure the ultimate objective of PPP procurement is achieve as planned.

The CSF with the lower factor loading in this group is sound economic policy with 0.668 (Table 4.3). Governments should adopt economic policies to maintain a stable and growing economic environment, where the private sector can operate with confidence. The economic policy affects the credibility of a price regimen and trust in the convertibility of the currency, which is essential for foreign investors. For projects where the major source of revenue to the private sector is generated from direct tariffs levied on users, there are revenue risks that can go beyond the control of the private sector such as, for example, future usage level and permitted tariff charges. There may also be unforeseen risks during the course of project life. To ensure project economic viability, the government may consider some forms of government guarantees, joint investment funding, or supplemental periodic service payments to allow the private sector cover the project costs and earn reasonable profits and investment returns. At the same time, the government should take due consideration of private sector's profitability requirements in order to have stable arrangements in PPP projects. Alternative sources of income and financing such as property development opportunities along the railway can be sought to bridge the funding gap for private investors.

\subsubsection{Factor Grouping 5- Political Support}

This factor group accounts for $8.90 \%$ (Table 4.3 ) of the total variability between critical success factors. Similar to factor grouping 2, this underlying group also consists of two CSFs including political support and transparency in the procurement process (process is made open and public). The CSFs in this group are related to the support given to PPP projects by government and also the procurement process that handle by government. The factor loadings for the CSFs political support and transparency in the procurement are 0.880 and 0.530 (Table 4.4) respectively. Politics has a close relationship with the development and implementation of public policy. A positive political attitude towards the private sector 
involved in an infrastructure project would support the growth of PPP. On the other hand, inadequate political support would pose a great risk to PPP projects. Successful PPP implementation requires a stable political environment, which in turn relies on the stability and capability of the host government. Political issues that go beyond private sector's domain should be handled by the government. In the event that the private sector participants are affected, they should be adequately compensated. Unstable political environments has resulted in some failed rail projects (e.g., frequent change in government premiers in Bangkok leading to the cancellation of many new public infrastructure projects originally procured under the PPP approach).

Besides, government should provides support in maintaining the transparency of whole procurement process by making sure the procurement process is open to the public. Transparency in procurement process enhances project value for money because a transparent procurement process is essential in lowering the transaction costs and shortening the time in negotiation and completing the deal. Clear projects' briefing and client requirements should help to achieve these in the bidding process. Transparency in tender processes, or negotiation, lies with the public client, private contractor and their advisers, which further suggests that three features are important for transparency: good communication between the public and private contractor and their advisers; the private sector openly consulting with the public sector and its adviser, while keeping responsibility for all decisions; and the private sector establishing a clear basis for making decisions. Transparency of process therefore requires effective communication that is open as far as possible to public scrutiny.

\subsubsection{Factor Grouping 6- Multi-benefit objectives}

This factor group accounts for $7.58 \%$ (Table 4.3 ) of the total variability between critical success factors. There is only one CSF component under this factor grouping: multi-benefit objectives (Table 4.4: significance 0.874). To develop a successful PPP/PFI project, all parties should agree on multi-benefit objectives. For a long-term partnership, PPP/PFI partners must understand and respect each other's goals. Typically, the objectives of the public sector party relate to reduction in financial restraints, avoiding public finance restriction, effective provision of public goods and services (detailed by specific project), the transfer of risk and the achievement of VFM. Private sector objectives are typically profit generation and market penetration, diversification and technology and skills acquisition, while the objectives of the stakeholder user communities are to receive better services or to occupy a better environment. Apart from the direct objectives in achieving public services, a PPP project needs to consider the private contractor's business objectives.

\section{CONCLUSION}

Mean score values of response data from survey respondents have been used to rank the relative importance of a catalogue of eighteen critical success factors in the Malaysian PPP environment. Five factors include commitment and responsibility of public and private sectors, transparency in procurement process, multi-benefit objectives, good governance and project technical feasibility- emerge as being most important in the development of successful Malaysian PPP projects.

From the analysis of ranking based on public and private sector groups, the results are mixed. While the majority of the success factors were ranked differently by the two sectors, there were a few factors of similar ranking for both groups. Despite the difference in the ranking for each of the 18 factors, the statistical test revealed that there is no significant difference in the perceptions of public and private sectors pertaining to the success factors of PPP implementation in Malaysia. This means that both group of respondents had similar opinions and expectation on the importance of each of the eighteen critical success factors in Malaysian PPP projects even the rankings of many factors were different between the public and private sectors.

The differences in the ranking of the CSFs between countries reflect the unique nature of PPP implementation in different countries. In other words, although PPP has been implemented worldwide, the nature and characteristics of PPP vary between countries. The findings imply that despite the needs for the government to learn the lessons concerning PPP implementation from other countries, the fact that the PPP success factors are unique to each country means that any policy, rule or regulation pertaining to PPP should 
be tailored to suit the practice of the specific country. In addition to that, CSFs often will change as the industry's environment changes, as the company's position within an industry change, or as particular problem or opportunity arises for that industry.

Given that all the factors are nominally regarded as critical in the literature, factor analysis was used to determine the principal success factor groupings that underlie project procurement. The findings showed that six underlying grouped factors accounting for $77 \%$ of the variance in responses were derived from the 18 CSFs. These six factor groupings are project implement, shared responsibility between public and private sector, government guarantee, efficient procurement process, political support and multi-benefit objectives. All loadings for the CSFs were greater than 0.5 indicating a high absolute value for each. It is noticed that the CSF appropriate risk allocation and risk sharing does not belong to any of the factor groupings, and therefore cannot be grouped in this way. The factor loading also showed that the underlying grouped factor is positively correlated to the criticality of individual factors of PPP and vice versa.

The six factor groupings therefore represent the basic elements of CSFs for PPP project development, and should always be considered by public sector sponsors in informing and shaping their PPP/PFI policy development, and by private sector concessionaires in managing their projects. The CSF of appropriate risk allocation and risk sharing lies outside these principal factor groupings for PPP projects in the Malaysian construction industry. However, this CSF is still related to the general environment of PPP hence are important and should be considered continuously throughout the project life.

Since PPP is at a germinating stage of development in Malaysia, a study of the CSFs should enable a better understanding of the important individual factors affecting the success or otherwise of PPP projects. Corresponding effective strategies based on those CSFs identified can also be generated for successfully delivering future PPP projects for accelerated excellence. It is believed that this paper has helped to depict the perspectives of public and private sectors' PPP experts in their evaluation of CSFs for PPP projects in Malaysia. Nevertheless, readers must take into consideration that there will be continuous evolution of the PPP project procurement process from the time of data collection and the time of research publication.

\section{ACKNOWLEDGMENT}

The authors are very grateful the civil engineers and civil experts in Malaysia for the questionnaire answering.

\section{REFERENCES}

[1] Hoppe, Eva I., David J. Kusterer, and Patrick W. Schmitz, Public-private partnerships versus traditional procurement: An experimental investigation, Journal of Economic Behavior \& Organization, vol. 89, pp.145$166,2013$.

[2] Abdul-Aziz, A-R., and PS Jahn Kassim, Objectives, success and failure factors of housing public-private partnerships in Malaysia, Habitat International, vol. 35, no. 1, pp. 150-157, 2011.

[3] Ros, Mohd Farmi Izudin Che, et al. "Fundamental elements of sustainable private financing initiative contracts." Business, Engineering and Industrial Applications (ISBEIA), 2011 IEEE Symposium on. IEEE, 2011.

[4] Ismail, Suhaiza, Critical success factors of public private partnership (PPP) implementation in Malaysia, AsiaPacific Journal of Business Administration, vol. 5, no.1, pp. 6-19, 2013.

[5] Cheung, E., Chan, A.P.C., Kajewski, S, Factors contributing to successful public private partnership projects: Comparing Hong Kong with Australia and the United Kingdom, Journal of Facilities Management, vol. 10, no. 1, pp.45-58, 2012.

[6] Li, B., Akintoye, A., Edwards, P.J., and Hardcastle, C., Critical success factors for PPP/PFI projects in the UK construction Industry, Construction Management and Economics, vol. 23, pp. 459-471, 2005. 
[7] Grimsey, D., and Lewis, M.K., Evaluating the risks of public private partnerships for infrastructure projects, International Journal of Project Management, vol. 20, no. 2, pp.107-18, 2002.

[8] Duffield, C.F., An evaluation framework for privately funded infrastructure projects in Australia, unpublished PhD thesis, Department of Civil and Environmental Engineering, University of Melbourne, Melbourne, 2001.

[9] Yuan, J., Zeng, A. Y., Skibniewski, M. J., and Li, Q., Selection of performance objectives and key performance indicators in public-private partnership projects to achieve value for money, Construction Management and Economics, vol. 27, pp.253 - 270, 2009.

[10] Li, B., Akintoye, A., Edwards, P.J., and Hardcastle, C, Critical success factors for PPP/PFI projects in the UK construction Industry, Construction Management and Economics, vol. 23, pp. 459-471, 2005.

[11] Li, B., Risk management of PPP projects, Unpublished PhD thesis, School of the built and natural environment. Glasgow Caledonian University. Glasgow, Scotland, 2003.

[12] Akintoye, A., Beck, M., Hardcastle, C., Chinyio, E., and Ansenova, D, Framework for risk assessment and management of private finance initiative projects, Glasgow Caledonian University, Scotland, 2001.

[13] Zou, W.W., Kumaraswamy, M., Chung, J., and Wong, J, Identifying the critical success factors for relationship management in PPP projects, International Journal of Project Management, vol. 32, no. 2, pp.265-274, 2014.

[14] Aayushi, G., A., Mahesh, C.G., Ranjan, A, Identification and ranking of critical success factors for BOT projects in India, Management Research Review, Vol. 36, no.11, pp.1040 - 1060, 2013.

[15] Pahlman, C., Build-operate-transfer (BOT)-private investment in public projects or just more public subsidies for the private sector?, Watershed, vol. 2, Towards Ecological Recovery and Regional Alliance, Bangkok, Thailand, 1996.

[16] Levy, S. M., Build, operate, transfer, Wiley, New York, 1996.

[17] Ogunlana, S. O, Build operate transfer procurement traps: examples from transportation projects in Thailand, Proc., CIB W92 Symp. on Procurement, IF Research Corporation, Montréal, pp. 585-594, 1997.

[18] Abdul-Aziz, A. R, Unraveling of BOT scheme: Malaysia's Indah Water Konsortium, J. Constr. Eng. Manage, vol. 127 , no. 6 , pp. $457-460,2001$.

[19] Jacobson, C., and Choi, S.O, Success factors: public works and public private partnerships, International Journal of Public Sector Management, vol. 21, no. 6, pp.637-657, 2008.

[20] Rockart, J.F., The changing role of the information systems executive: a critical success factors perspective, Sloan Management Review, vol. 24, no. 1, pp. 3-13, 1982.

[21] Tiong, R., Critical success factors in winning BOT contracts, J. Constr. Eng. Manage, vol. 118, no. 2, pp. 217$28,1992$.

[22] Cooke-Davies, T., The 'real' success factors on projects, International Journal of Project Management, vol. 20, no. 3, pp. 185-90, 2002.

[23] Suhaiza, I., Critical success factors of public private partnership (PPP) implementation in Malaysia, Asia-Pacific Journal of Business Administration, vol. 5, no. 1, pp.6 - 19, 2013.

[24] Qiao, L., Wang, S.Q., Tiong, R.L.K. and Chan, T.S., Framework for critical success factors of BOT projects in China, Journal of Project Finance, vol. 7, no. 1, pp. 53-61, 2001.

[25] Pinder, J., Smith, A., Pottinger, G. and Dixon, T., Project management and the private finance initiative, Project Report, Royal Institution of Chartered Surveyors, London, 2004. 
[26] Kwak, Y.H., Chih, Y.Y. and Ibbs, C.W., Towards a comprehensive understanding of public private partnerships for infrastructure development, California Management Review, vol. 51, no. 2, pp. 51-78, 2009.

[27] Wong, A, Lessons learned from implementing infrastructure PPPs - a view from Singapore, paper presented at Seminar jointly organized by the Department of Civil Engineering of the University of Hong Kong and Civil Division of the Hong Kong Institution of Engineers, June 13, 2007.

[28] Jefferies, M., Gameson, R., and Rowlinson, S, Critical success factors of the BOOT procurement system: reflections from the Stadium Australia case study, Engineering, Construction and Architectural Management, vol. 9, no. 4, pp.352 - 361, 2002.

[29] Khang, D.G. (1998), Hopewell's Bangkok Elevated Transport System (BETS), School of Management, AIT, Bangkok.

[30] Sanvido, Victor, et al. "Critical success factors for construction projects." Journal of construction engineering and management 118.1 (1992): 94-111.

[31] Li, B. (2003), "Risk management of construction public private partnership projects", PhD thesis, Glasgow Caledonian University, Glasgow.

[32] Jamali, D. (2004), "Success and failures mechanisms of public private partnerships (PPPs) in developing countries", The International Journal of Public Sector Management, Vol. 17 No. 5, pp. 414-30.

[33] Zhao, Zhen-Yu, et al. "Critical success factors for BOT electric power projects in China: Thermal power versus wind power." Renewable energy 35.6 (2010): 1283-1291.

[34] Azmi and Associates. (2008). "Private Finance Initiatives as Part Of the 9th Malaysia Plan", Retrieved January 14, 2014 http://www.azmilaw.com.my/archives/Article_6

[35] United Nations Economic Commission for Europe (UNECE) (2007). "A guide to promoting good governance in public private partnerships.” Retrieved June 14, 2013

[36] Badshah, A. (1998). "Good Governance for Environmental Sustainability, Public Private Partnerships for the Urban Environment Programme (PPPUE)”, United Nations Development Program, UNDP, New York

[37] Mustafa, A. (1999). "Public-private partnership: an alternative institutional model for implementing the private finance initiative in the provision of transport infrastructure", Journal of Project Finance, 5, pp.64-79.

[38] National Audit Office (NAO) (1999). "Examining the Value for Money of Deals under the Private Finance Initiative", NAO, London.

[39] Asian Development Bank (ADB) (2008). "Public-private partnership handbook", Asian Development Bank.

[40] Sanvido, Victor, et al. "Critical success factors for construction projects." Journal of construction engineering and management 118.1 (1992): 94-111.

[41] Li, B. (2003), "Risk management of construction public private partnership projects", PhD thesis, Glasgow Caledonian University, Glasgow.

[42] Jamali, D. (2004), "Success and failures mechanisms of public private partnerships (PPPs) in developing countries", The International Journal of Public Sector Management, Vol. 17 No. 5, pp. 414-30.

[43] Zhao, Zhen-Yu, et al. "Critical success factors for BOT electric power projects in China: Thermal power versus wind power." Renewable energy 35.6 (2010): 1283-1291.

[44] Azmi and Associates. (2008). "Private Finance Initiatives as Part Of the 9th Malaysia Plan", Retrieved January 14, 2014 http://www.azmilaw.com.my/archives/Article_6 
[45] United Nations Economic Commission for Europe (UNECE) (2007). "A guide to promoting good governance in public private partnerships.” Retrieved June 14, 2013.

[46] Badshah, A. (1998). "Good Governance for Environmental Sustainability, Public Private Partnerships for the Urban Environment Programme (PPPUE)”, United Nations Development Program, UNDP, New York.

[47] Mustafa, A. (1999). "Public-private partnership: an alternative institutional model for implementing the private finance initiative in the provision of transport infrastructure", Journal of Project Finance, 5, pp.64-79.

[48] National Audit Office (NAO) (1999). "Examining the Value for Money of Deals under the Private Finance Initiative", NAO, London.

[49] Asian Development Bank (ADB) (2008). "Public-private partnership handbook", Asian Development Bank.

\section{NHŨNGG NHÂN TỐ (CSFs) CHO MÔ HÌNH HợP TÁC CÔNG TƯ (PPP) Ở MALAYSIA}

Tóm tắt. Hợp tác Công tư (PPP) là một sự lựa chọn ngày càng phổ biến cho các nhà hoạch định chính sách trong việc thực hiện các dự án công cộng quan trọng. Để đảm bảo các mục tiêu cuối cùng của PPP / PFI, xác định các nhân tố thành công chủ chốt (CSFs) của việc thực hiện PPP là rất quan trọng. Đối với các quốc gia mới áp dụng PPP, thậm chí còn quan trọng hơn để xác định các nhân tố thành công nhằm tối đa hóa lợi ích của phương pháp này và giảm rủi ro cho tất cả các bên liên quan. PPP đã được chính thức công bố tại Malaysia theo Kế hoạch Malaysia lần thứ IX vào năm 2006. Kể từ đó, nhiều dự án của chính phủ đã được chuyển qua PPP. Trong nghiên cứu này, các nhân tố được coi là quan trọng cho sự thành công của việc thực hiện dự án PPP ở Malaysia đã trở thành một đề tài để nghiên cứu. Chuyên gia phân tích và khảo sát đã được sử dụng trong trường hợp này. Các phát hiện cho thấy $17 \mathrm{CSF}$ s có thể được phân thành 6 nhân tố cơ bản. Sự đóng góp chính của nghiên cứu này là bổ sung và nâng cao kiến thức trong quản lý các dự án PPP bằng cách nghiên cứu tầm quan trọng tương đối của CSF liên quan đến các dự án xây dựng PPP ở Malaysia. Một số kiến nghị đã được đề xuất để cải thiện hiệu suất tổng thể của sự cung ứng PPP của Malaysia.

Từ khóa. Mô hình hợp tác công - tư, Nhân tố thành công chủ chốt, Malaysia.

Ngày nhận bài: 29/09/2017

Ngày chấp nhận đăng: 31/12/2017

C 2017 Trường Đại học Công nghiệp thành phố Hồ Chí Minh 